\title{
Investigating the effects of various factors on bank deposits
}

\author{
Mohammad Khodaei Valahzaghard ${ }^{\mathrm{a}^{*}}$ and Seyyedeh Masoumeh Kash $\mathrm{fi}^{\mathrm{b}}$
}

\begin{tabular}{|c|c|}
\hline CH RON I C LE & A B S T RACT \\
\hline $\begin{array}{l}\text { Article history: } \\
\text { Received July } 28,2013 \\
\text { Received in revised format } \\
20 \text { November } 2013 \\
\text { Accepted } 14 \text { January } 2014 \\
\text { Available online } \\
\text { February } 172014 \\
\text { Keywords: } \\
\text { Bank deposit } \\
\text { Growth domestic products } \\
\text { Financial deepening } \\
\text { Banking industry }\end{array}$ & $\begin{array}{l}\text { This paper performs an investigation on the effects of seven variables including growth } \\
\text { domestic product, financial deepening, inflation rate, dependency burden, the number of bank's } \\
\text { branches, inflation rates given/charged on bank deposit. The study has been performed on one } \\
\text { of Iranian banks named Sina Bank over the period 2006-2011. The implementation of } \\
\text { individual regression analysis has detected a positive and meaningful relationship between } \\
\text { growth domestic product, financial deepening, inflation rate and the number of branches on one } \\
\text { side and bank deposit on the other side. In addition, the study has confirmed a negative and } \\
\text { meaningful relationship between two variables of dependency burden as well as interest } \\
\text { charged on bank's clients and bank deposit. However, the result of our survey does not indicate } \\
\text { that there was any relationship between interest rate paid to customers and bank deposit. }\end{array}$ \\
\hline
\end{tabular}

\section{Introduction}

During the past few years, there have been various unpleasant incidents in world on banking industry. Many well-known banks faced financial turmoil and filed for bankruptcy. Therefore, it is essential to study the effects of different factors on banking industry (Fisher, 1974). Lajeri and Dermine (1999), for instance, evaluated the effect of unexpected inflation on the stock returns of a sample of French banks by offering an empirical investigation of theories to predict the effect of inflation on the stock returns of banks. They reported that, in periods of volatile inflation, there was an inflation risk factor, which was independent of the well-documented interest rate factor. Hamori and Hashiguchi (2012) used an unbalanced panel data analysis of 126 countries over the period 1963-2002 to study the effects of financial deepening on inequality. They stated that financial deepening could reduce inequality while economic growth could reduce the equalizing effects of financial deepening. *Corresponding author. Tel: +98-912-3443139

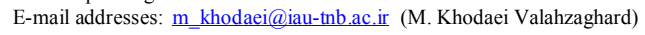


Besides, they reported that inequality could increase with an increase in trade openness and the disequalizing effects of trade openness could decrease as a country grows. They also reported that financial deepening and trade openness had asymmetric impacts on inequality.

Bank deposit may influence growth domestic product, significantly (Nicolo et al., 2005). Phillips and Chen (2011), for instance, used multiple imputation techniques on a panel data from 1978 to 1999 for 30 provinces, autonomous regions, and independently administered cities and reported that provinces with more innovation capital and more bank-deposit-to-GDP ratios would more likely to experience higher economic growth.

Carbo-Valverde et al. (2011) performed an investigation on bank deposit and confirmed the existence of the trade-off between exploiting old customers and attracting new ones. According to Johannesen (2014), bank deposits in offshore financial centers may be implemented to evade taxes on interest income. Pérez Montes (2013) investigated the impact of interbank and public debt markets on the competition for bank deposits. He reported that the interbank rate was correlated with the return on deposits than the interest rate on public debt, but the connection between interbank rates and deposit returns was substantially weaker in the crisis period 2008-2010. Nicolo et al. (2005) evaluated the advantages and risks associated with dollarization of bank deposits and provided some empirical evidence on the determinants of deposit dollarization, its role in promoting financial development, and on whether dollarization is associated with financial instability. They reported that the credibility of macroeconomic policy and the quality of institutions could be considered as the key determinants of cross-country variations in dollarization.

\section{The proposed study}

In this paper, we study the effects of various factors on bank deposits in one of Iranian banks named Sina bank. The proposed study considers the following seven hypotheses.

1. There is a meaningful relationship between bank deposits and growth domestic products (GDP).

2. There is a meaningful relationship between bank deposits (Bank Deposit) and financial deepening (FD).

3. There is a meaningful relationship between bank deposits and inflation rate (IR).

4. There is a meaningful relationship between bank deposits and dependency burden (DB).

5. There is a meaningful relationship between banks deposits and the number of bank's branches (BRANCH).

6. There is a meaningful relationship between banks deposits and interest rate paid to bank's customers (PsRate).

7. There is a meaningful relationship between banks deposits and interest rate charged to bank's customers (IntRate).

The proposed study of this paper considers the following econometrics model to examine different hypotheses of the survey,

Bank Deposit $=\beta_{0}+\beta_{1} G D P+\beta_{2} F D+\beta_{3}$ Inflate $+\beta_{4}$ Intrate $+\beta_{5} D B+\beta_{6}$ Branch $+\beta_{7}$ Psrte $+\varepsilon$ 
The proposed study of this paper has been performed on one of Iranian banks named Sina over the period 2006-2011. Table 1 and Table 2 show details of our some basic statistics associated with sample data.

Table 1

The summary of some basic statistics

\begin{tabular}{ccccc}
\hline & BRANCH & EB & FD & GDP \\
\hline Mean & 410.3030 & 277.5345 & $1.95 \mathrm{E}+08$ & 2137535. \\
Median & 153.5000 & 245.2531 & $1.64 \mathrm{E}+08$ & 2128978. \\
Maximum & 3692.000 & 743.0000 & $3.82 \mathrm{E}+08$ & 2654123. \\
Minimum & 2.000000 & 97.64864 & 89655780 & 1691814. \\
Std. Dev. & 666.2835 & 137.1065 & 94934791 & 293712.0 \\
Skewness & 2.818472 & 1.099548 & 1.023197 & 0.313406 \\
Kurtosis & 11.89163 & 4.066309 & 2.877663 & 2.570724 \\
Jarque-Bera & 304.7997 & 16.42585 & 11.55741 & 1.587218 \\
Probability & 0.000000 & 0.000271 & 0.003093 & 0.452210 \\
Sum & 27080.00 & 18317.28 & $1.29 \mathrm{E}+10$ & $1.41 \mathrm{E}+08$ \\
Sum Sq. Dev. & 28855690 & 1221883. & $5.86 \mathrm{E}+17$ & $5.61 \mathrm{E}+12$ \\
Observations & 66 & 66 & 66 & 66 \\
\hline
\end{tabular}

Table 2

The summary of some basic statistics

\begin{tabular}{ccccc}
\hline & INFLATE & INTRATE & PSRATE & TD \\
\hline Mean & 16.50833 & 14.25000 & 1256.682 & 2.700000 \\
Median & 15.22500 & 15.00000 & 1140.000 & 2.700000 \\
Maximum & 25.40000 & 15.50000 & 2797.500 & 2.900000 \\
Minimum & 11.90000 & 12.00000 & 336.0000 & 2.400000 \\
Std. Dev. & 5.069658 & 1.476092 & 544.1833 & 0.183973 \\
Skewness & 0.593391 & -0.577 & 0.610203 & -0.329 \\
Kurtosis & 1.972716 & 1.532378 & 2.867670 & 1.740000 \\
Jarque-Bera & 6.775355 & 9.580564 & 4.143976 & 5.553900 \\
Probability & 0.033787 & 0.008310 & 0.125935 & 0.062228 \\
Sum & 1089.550 & 940.5000 & 82941.00 & 178.2000 \\
Sum Sq. Dev. & 1670.593 & 141.6250 & 19248806 & 2.200000 \\
\hline Observations & 66 & 66 & 66 & 66 \\
\hline
\end{tabular}

Based on the results of Table 2 and Table 3, we may wish to perform regression analysis to study the relationship between bank deposit as dependent variable and other independent variables. However, we first have to determine whether we should assume equal intercept or variable intercept and this is accomplished through Chaw test, which yields a significant value. Therefore, we use Panel data for testing the relationships. In addition, Hausman test guide us to use random effect to study the model.

\section{The results}

In this section, we present details of our findings on testing various hypotheses of the survey.

\subsection{The first hypothesis: The effect of GDP on bank deposit}

The first hypothesis of this survey investigates the relationship between bank deposit and GDP. The implementation of regression function yields the following relationship,

$$
\begin{aligned}
& \text { Bank Deposit }=-388.0677+0.000311 \text { GDP } \\
& \text { t-student } \quad-6.492184 \quad 11.23825 \\
& \text { Sig. } \quad 0.000 \quad 0.000 \quad \mathrm{R}^{2}=0.809 \mathrm{DW}=1.792
\end{aligned}
$$


As we can observe from the results of regression function given in Eq. (1), there is a meaningful relationship between GDP and bank deposit when the level of significance is one percent. R-Square value is equal to 0.809 , which means GDP estimates approximately $81 \%$ of the changes of bank deposit. Durbin-Watson value is equal to 1.792 , which means there is no auto correlation among residuals. These results confirm the first hypothesis of the survey.

\subsection{The second hypothesis: The effect of FD on bank deposit}

The second hypothesis of this survey investigates the relationship between bank deposit and financial deepening (DP). We have performed the regression analysis and the results are as follows,

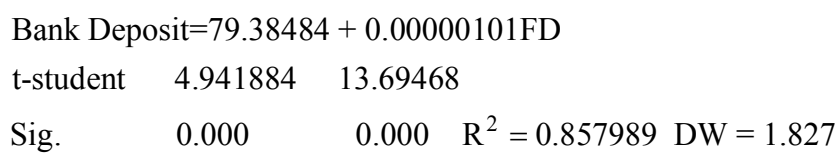

The result of regression function given in Eq. (2) indicates that there was a meaningful relationship between FD and bank deposit when the level of significance is one percent. R-Square value is equal to 0.857989 , which means financial deepening represents approximately $86 \%$ of the changes of bank deposit. Durbin-Watson value is equal to 1.827 , which means there is no auto correlation among residuals. These results confirm the second hypothesis of the survey and we can conclude that there was a positive and meaningful relationship between financial deepening and bank deposit.

\subsection{The third hypothesis: The effect of inflation rate on bank deposit}

The third hypothesis of this survey tries to understand the relationship between bank deposit and inflation rate (IR). The implementation of the regression analysis yields the following,

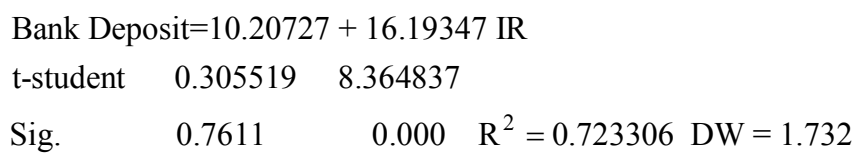

As we can observe from the results of Eq. (3), there is a meaningful and positive relationship between IR and bank deposit when the level of significance is one percent. R-Square value is equal to 0.723306 , which means inflation rate represents approximately $72 \%$ of the changes of bank deposit. Durbin-Watson value is equal to 1.732 , which means there is no auto correlation among residuals. The results have confirmed the third hypothesis of the survey and we can conclude that there was a positive and meaningful relationship between inflation rate and bank deposit.

\subsection{The fourth hypothesis: The effect of dependency burden (DB) on bank deposit}

The fourth hypothesis of this survey attempts to investigate the relationship between bank deposit and dependency burden (DB). The implementation of the regression analysis yields the following,

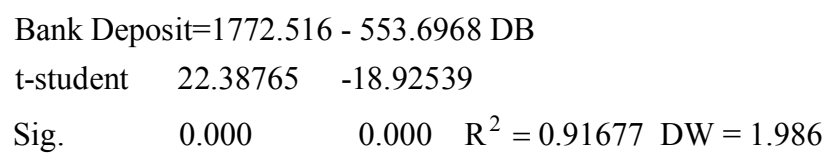

The results of Eq. (4) specify that there was a meaningful and negative relationship between DB and bank deposit when the level of significance is one percent. R-Square value is equal to 0.91677, which means dependency burden (DB) represents approximately $92 \%$ of the changes of bank deposit. Durbin-Watson value is equal to 1.986 , which means there is no auto correlation among residuals. 
The results have confirmed the fourth hypothesis of the survey and we can conclude that there was a negative and meaningful relationship between dependency burden and bank deposit.

\subsection{The fifth hypothesis: The effect of the number of branches (BRANCH) on bank deposit}

The fifth hypothesis of this survey studies the relationship between bank deposit and the number of branches (BRANCH). The implementation of the regression analysis yields the following,

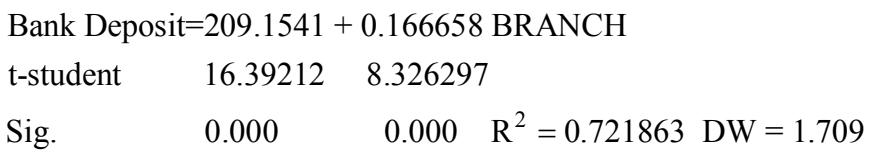

Based on the results of Eq. (5), there is a meaningful and positive relationship between BRANCH and bank deposit when the level of significance is one percent. R-Square value is equal to 0.721863 , which means the number of branches represents approximately $72 \%$ of the changes of bank deposit. Durbin-Watson value is equal to 1.709 , which means there is no auto correlation among residuals. The results have confirmed the fifth hypothesis of the survey and we can conclude that there was a positive and meaningful relationship between the number of branches and bank deposit.

\subsection{The sixth hypothesis: The effect of the interest rate (PsRate) on bank deposit}

The sixth hypothesis of this survey studies the relationship between bank deposit and the interest rate paid to bank's clients. The results of regression analysis is as follows,

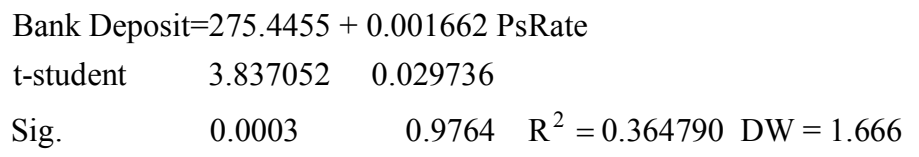

According to the results of Eq. (6), there is not any meaningful relationship between PsRate and bank deposit when the level of significance is one percent or even ten percent. Therefore, the sixth hypothesis of the survey has not been confirmed and we can conclude that interest rate paid to bank's customers does not play an essential role on absorbing more deposit.

\subsection{The seventh hypothesis: The effect of the interest rate (IntRate) on bank deposit}

The seventh hypothesis of this survey studies the relationship between bank deposit and the interest rate charged to bank's clients. The results of regression analysis is as follows,

$$
\begin{array}{lcc}
\text { Bank Deposit= } & 1190.944- & 64.09889 \text { IntRate } \\
\text { t-student } & 16.49502 & -12.71773 \\
\text { Sig. } & 0.0003 & 0.0000 \quad \mathrm{R}^{2}=0.841004 \mathrm{DW}=1.870
\end{array}
$$

Based on the results of Eq. (7), there is a meaningful and negative relationship between IntRate and bank deposit when the level of significance is one percent. R-Square value is equal to 0.841004 , which means interest rate charged on bank customers represents approximately $84 \%$ of the changes of bank deposit. Durbin-Watson value is equal to 1.870 , which means there is no auto correlation among residuals. The results have confirmed the last hypothesis of the survey and we can conclude that there was a negative and meaningful relationship between the interest rate charged on bank's clients and bank deposit. 
In summary, the investigation on the effects of seven individual factors on bank deposit has confirmed six hypotheses. We have also used stepwise regression analysis and Eq. (8) shows the results of our survey,

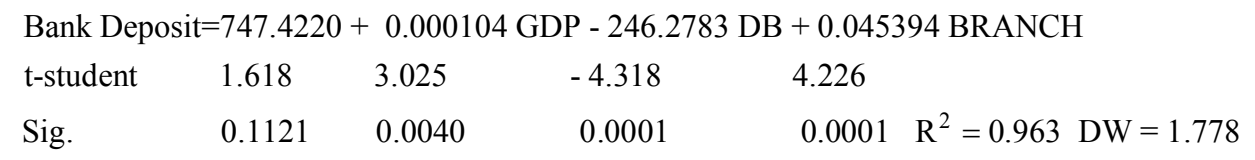

The results of combined regression analysis indicate that three factors including growth domestic product, dependency burden as well as the number of branches all together could describe approximately $96 \%$ of the changes on bank deposit. These three factors could approximately describe $96 \%$ of the changes on bank deposit.

\section{Conclusion}

This paper has performed an investigation to study the effects of different variables on bank deposit in an Iranian banking industry over the period 2006-2011. The implementation of individual regression analysis has detected a positive and meaningful relationship between growth domestic product, financial deepening, inflation rate and the number of branches on one side and bank deposit on the other side. In addition, the study has confirmed a negative and meaningful relationship between two variables of dependency burden as well as interest charged on bank's clients and bank deposit. However, the result of our survey does not indicate that there was any relationship between interest rate paid to customers and bank deposit.

\section{Acknowledgement}

The authors would like to thank the anonymous referees for constructive comments on earlier version of this paper.

\section{References}

Carbo-Valverde, S., Hannan, T. H., \& Rodriguez-Fernandez, F. (2011). Exploiting old customers and attracting new ones: The case of bank deposit pricing. European Economic Review, 55(7), 903915.

Fisher, I. (1974). The Theory of Interest, Augustus M. Kelley Publisher, Clifton on Hatch, B.C. Johnson, S.A. The impact of specialist firms acquisitions market quality, Journal of Financial Economics, 66, 139-167.

Hamori, S., \& Hashiguchi, Y. (2012). The effect of financial deepening on inequality: Some international evidence. Journal of Asian Economics, 23(4), 353-359.

Johannesen, N. (2014). Tax evasion and Swiss bank deposits. Journal of Public Economics, 111, 4662.

Lajeri, F., \& Dermine, J. (1999). Unexpected inflation and bank stock returns: The case of France 1977-1991. Journal of Banking \& Finance, 23(6), 939-953.

Nicolo, G. D., Honohan, P., \& Ize, A. (2005). Dollarization of bank deposits: Causes and consequences. Journal of Banking \& Finance, 29(7), 1697-1727.

Phillips, K. L., \& Chen, B. (2011). Regional growth in China: An empirical investigation using multiple imputation and province-level panel data. Research in Economics, 65(3), 243-253.

Pérez Montes, C. (2013). The impact of interbank and public debt markets on the competition for bank deposits. The Spanish Review of Financial Economics, 11(2), 57-68. 